https://doi.org/10.48009/2_iis_2008_421-428

\title{
INFLUENCE OF TRUST PREDICTORS ON DIFFERENT DIMENSIONS OF TRUST IN M-COMMERCE
}

\author{
Sunitha Mogenahalli, Illinois State University, snatara@ilstu.edu \\ Pruthikrai Mahatanankoon Illinois State University, pmahata@ilstu.edu \\ Billy B. L. Lim, Illinois State University, bllim@ilstu.edu
}

\begin{abstract}
Mobile commerce merchants have critical concerns establishing consumers' trust, which is known to be one of the major contributors of mobile commerce success. Our study explores various dimension of trust and proposes that a multi-dimensional trust supersedes a single measure of trust. Applying stepwise multiple regression analyses, the results show that the multi-dimensional trust (i.e., acceptance, competence, benevolence, and integrity) reveals more detail information regarding the nature of mobile applications and services. Practitioners and researchers can use this finding to investigate multi-dimensional trust in the mobile commerce settings.
\end{abstract}

Keywords: M-commerce, M-commerce vendors, Trust, Trust Dimensions, Trust Predictors

\section{INTRODUCTION}

M-commerce is considered an emerging subset of ecommerce that encompasses mobile devices, applications, middleware, and wireless networks [18, 23]. Similar to e-commerce, m-commerce can be transactional (buying products or services), nontransactional (browsing products or services) or both. Over the past years many firms have been focusing on enhancing their software and hardware platforms for m-commerce. This has lead to a notable and steady increase in m-commerce users. M-commerce has become a new access channel to financial products and services for mobile users. According to Juniper Research, m-commerce will be a US $\$ 88$ billion industry by 2009. The research reveals that although the commerce of digital goods such as ring tones, games, wallpaper, music, etc. will continue to dominate the mobile market, other services such as ticket purchasing will also emerge and account for over $44 \%$ of the $\$ 88$ billion global m-commerce business [7].

Although m-commerce is a subset of e-commerce, $\mathrm{m}$ commerce applications cannot be easily built by just upgrading the existing e-commerce applications. This process would involve specific mindfulness not only from the technology perspective but also from the business perspective [22]. Trust, which may be defined as "the assured reliance on the character, ability, strength or truth of someone or something or as confidence in or reliance on some quality or attribute of a person or a thing or the truth of a statement" [1] has always been an issue in ecommerce. But it is a much bigger issue in mcommerce, due to its unique medium [24]. The very nature of wireless is the basis for the lack of trust in m-commerce. This is because consumers are suspicious of the reliability and security of the services provided by their m-commerce vendors, which are third party providers of m-commerce transactions and services. Thus, acquiring customer trust is imperative to the success of any m-commerce vendor. The vendors first need to gain the customer's trust, before conducting any business with the customer. As a part of this research we are trying to empirically examine the influence of trust predictors on the different dimensions of trust in m-commerce.

\section{BACKGROUND AND LITERATURE REVIEW}

The importance of trust in commerce has been emphasized by many research studies. Trust has been the focal point in all economic transactions because of a deep seated human need to understand their social surroundings, i.e., to identify when, why, and how others behave [6]. With no proven guarantees available that the vendor will not engage in harmful opportunistic behavior, trust becomes crucial in any kind of economic transaction. The unique feature of a radio-based wireless device makes gaining customers trust a difficult task. Trust in a vendor may eliminate the fear of using the vendor's m-commerce services.

Through literature review we were able to identify that customer trust in m-commerce is a result of a number of causal factors. Many of these factors are rooted in e-commerce systems but with a mobility and/or portability twist. Each of the factors is explained in detail below. 


\section{User Interface Design}

User interface provides the customer with the first impression about the service provider and their trustworthiness. It is the channel through which the customer communicates, performs information search, and transactions. Due to small screens, low resolution displays, and tiny multi-functional keypads, providing simplicity of use on a mobile device depends on a good user interface design. Easy access to information and simplicity of navigation are the two important antecedents for the successful completion of any online transaction [4]. Mcommerce websites cannot be designed by just shrinking e-commerce websites to fit small screens. It requires a significant amount of design effort to ensure that the site navigation is not cumbersome and users can find information with minimal effort [28, 23]. It has been proved that consumers perceive easier-to-use systems to be more useful as they would not be wasting time figuring out how to use the system [3]. It is expected that a pleasant user experience would encourage return business from consumers for m-commerce vendors.

\section{Ubiquitous Connectivity}

The use of wireless technologies in m-commerce extends the nature and scope of traditional ecommerce by providing additional features like mobility and portability [12]. Ubiquitous connectivity is the ability of consumers to access information at the point of need regardless of their location [14]. The ubiquitous nature of mobile devices has drastically changed the way people interact, for work or recreation [8]. The convenient access to relevant information or real time services has made people's lives much easier. Ubiquitous connectivity adds to the perceived usefulness of the services provided by the m-commerce vendors, which would have an impact on customer's transaction intentions [14].

\section{Contextual Offers}

Contextual offers can be defined as "the extent to which marketers provide consumers with optimal information or service that is contextually relevant to them based upon customer profile, position, and time information" [14]. Context in mobile computing can be defined as a set of environmental states or settings of the customer that determines the application's behavior or an occurrence of an application event in the interest of the customer. M-commerce vendors can use the information regarding customer's identity, position, access time, and profiles to provide them with optimal information or services, which are contextually relevant to them at the point of need [13]. Contextual offers can often lead to purchases because of its ability to reach potential buyers at the time and place where the buying decision is made.

\section{Service Quality}

Service quality can be defined as the difference between the customers expectation about the quality of service before using the service and their perception of service quality after they use the service [2]. Service quality in m-commerce can be explained using performance metrics such as response time, throughput, and availability. Ubiquitous feature of mobile devices can be fully utilized only when m-commerce service's availability, response time, and throughput are acceptable. M-commerce services should try to diminish any kind of uncertainty among the customers. They should provide customers with confirmation of actions like emails exemplifying the successful transactions or a description of error if any that occurred during the transaction. Steps like these would enhance the customer's trust and convey an impression of the vendor's competence [1]. Attracting new customers and retaining old ones are largely dependent on the quality of service offered by the m-commerce vendor.

\section{Service Description}

Service description refers to the accurate, timely, and useful information provided by the m-commerce vendors in their mobile websites. The m-commerce website, being the only interface between the vendor and the customer, has to be designed in such a way that it provides a comprehensive description about the services/products [23]. With mobile device constraints such as limited processing power, low bandwidth, small screen, and low resolution display, a well designed service description plays a critical role in enhancing the consumer adoption of the new technology. Araujo and Araujo [1] in their work suggest that a complete product or service description, pictures of the products if available, features and price comparisons, and external links should be incorporated to support the decisionmaking process. A good quality service description has a direct impact on potential customer's perception.

\section{Customer Support}

Customer support is the support service provided by the m-commerce vendor regarding their services/products. Customer support, being the only 
direct means of communication for the customer, has a major influence on trust formation. Communication between the customers and the vendor's support service should be clear and an effort should be made to reduce information asymmetry [23]. Araujo and Araujo [1] suggest that if a customer's concerns and questions are not addressed effectively and quickly, the customer could choose a different vendor. Goodwill shown in the communications with the customer portrays an image of credibility and trustworthiness, making the customer feel more comfortable with the m-commerce vendor [23].

\section{User and Security Control}

Providing the customers with the controls over the use of the mobile website will induce a sense of confidence in the customer. Ease of use and speed of use, which are the most important factors influencing the adoption of multimedia mobiles services, can be achieved by allowing the users to customize the mobile website [13]. The customers should have complete control over their personal data. They should be able to decide if their information can be disclosed to third party or not and have the ability to alter their information if needed [1]. Customization and personalization of a website by the customer increases the usability of that m-commerce website [10].

\section{Privacy Policies}

Mobility of the mobile device and the communication medium in m-commerce arouse lot of privacy concerns among the m-commerce customers. Privacy policies posted on m-commerce websites play a major role in lessening the privacy concerns among the customers. They represent a means by which mcommerce vendors can demonstrate that they are not opportunistic with regard to customer's personal or transactional information [23]. Liu and Arnett [15] propose that a privacy policy should be comprehensive and include all elements of the principle of fair information practices.

\section{Incentives}

Incentive can be defined as either financial or nonfinancial factor that provides a motive or a reason for making a choice. M-commerce service providers can use incentives as a means to attract customers. When incentives provide low priced products or services of comparable quality through m-commerce, the difference in price of the service or product from traditional shopping outlet is considered as gain by the customer. This perceived gain coupled with other factors such as convenience, better quality product, etc. will reduce the risk of the transaction [21].

\section{Reputation}

Reputation in m-commerce can be defined as the opinion of the customers regarding the services provided by the m-commerce vendors. Customers feel more comfortable and confident doing business with a reputed vendor. Reputation of an m-commerce vendor is formed primarily by the feedback provided by customers. M-commerce companies can form virtual communities similar to the ones formed by ecommerce sites (e.g., Amazon, eBay, etc.) in which members can exchange experiences and help build the reputation of the m-commerce vendor [23]. Mcommerce communities provide enormous opportunities for many to exchange views and experiences about the m-commerce services/products with each other [29].

\section{Third Party Support}

Third party seals or icons on m-commerce websites are designed to communicate to the customers that the m-commerce vendor conforms to the assuror's specific standards or requirements and as a result can be trusted by the customers [11]. M-commerce service providers can build transference-based trust by associating themselves with already-trusted businesses or by placing icons on their web sites from "trusted" third parties [19].

With the above related work serving as the base, this study combines different trust predictors considered by various researchers and creates a comprehensive model that is based on multiple dimensions of trust for m-commerce. The model consolidates the dimensions of trust that are considered by some but not others and builds a relationship between trust predictors and different dimensions of trust in $\mathrm{m}$ commerce. This study gives researchers a new perspective of trust in m-commerce and allows for further study to investigate along different dimensions of trust in m-commerce.

\section{RESEARCH METHODOLGY}

As a part of the research we did an exploratory study to examine how different $\mathrm{m}$-commerce characteristics influence trust. The study proposes that a multidimension trust (i.e., acceptance, competence, benevolence, and integrity) is better than a single dimension of trust. To empirically test this assertion, a questionnaire was developed using existing instruments from existing literature. The final 
respondents were seventy undergraduate and graduate students from information technology major.

Trust has been considered to have different dimensions by many authors [3, 5, 16, 23, 27]. By doing a comprehensive study of the literature we can deduce that trust is a four dimensional quantity as described below.

\section{Acceptance Trust}

Acceptance trust can be defined as the behavior of the customer willing to try out new technology. Lu, $\mathrm{Yu}$, Liu, and Yao [16] in their work suggest that success of wireless internet services is completely dependent on user acceptance of new technology. This notion is seconded by Kumar and Gordan [3] who believe that the success of $\mathrm{m}$-commerce hinges on the customer's willingness to accept new technology and engage in activities that would involve using new systems or devices different from what they are used to in the past.

\section{Competence Trust}

Competence trust, which emerges from economic foundation [23], can be considered as the information about the m-commerce service provider that helps the customer differentiate between trustworthy and untrustworthy service providers. Tan and Sutherland [27] define competence trust as the belief developed by consumers in the service provider's abilities, skills and expertise that the expected level of service will be accomplished. Siau and Shen [23] also concur and state that competence trust is one of the important factors in gaining trust in e-commerce. We can infer that this holds true for m-commerce as well as it a subset of e-commerce.

\section{Benevolence Trust}

Benevolence trust can be explained as the belief developed by the customer that the service provider wants to do good for the customer and is not solely interested in making profit [27]. An important aspect of gaining online customer trust according to Siau and Shen [23] is to develop benevolence trust in the vendor. Gefen [5], supporting the above belief, defines benevolence as a one of the trustworthiness beliefs that influences overall trust in e-commerce. We theorize that benevolence trust is equally important in m-commerce, which is a subset of ecommerce.

\section{Predictability and Integrity trust}

Predictability trust is a belief that the service provider will act in a consistent manner and integrity trust is a belief that the service provider acts in an honest manner and adheres to accepted set of principles or standards [27]. This idea is supported by Siau and Shen [23] and Gefen [5] who add that these factors play a major role in influencing overall trust in ecommerce. Predictability trust and Integrity trust apply to m-commerce as well, as both m-commerce and e-commerce are governed by similar principle of commerce.

These different dimensions of trust must be significantly correlated to a single dimension of trust to signify the similarities among these measurements. Therefore, we propose that

H1: There is a positive correlation between trust and multi-dimensional trust.

Ease of use and usefulness can be considered as two beliefs influencing acceptance trust [6]. Zhang and Zhang [30], in utilizing the Technology Acceptance Model in their work related to e-commerce, identify perceived usefulness as the users perception of how useful the website is and perceived ease of use as the users perception of how simple the website is to use. Building upon their work, in m-commerce we can consider perceived ease of use as the simplicity to conduct business on a mobile device that depends on user interface design of the mobile website. Furthermore, features such as ubiquitous connectivity and contextual offers add to the perceived usefulness of the services provided by the m-commerce vendors [14]. Thus we can consider user interface design, ubiquitous connectivity, and contextual offers as the factors influencing Acceptance Trust.

H2: User interface design, ubiquitous connectivity, and contextual offers have positive influence in developing acceptance trust in mobile commerce vendors.

As stated earlier, competence trust is the belief developed by customers in the service provider's abilities, skills, and expertise that the expected level of service will be accomplished [27]. When a customer is satisfied with the services provided by the m-commerce vendor, he/she by virtue of the satisfaction develops competence trust in the vendor. Customer satisfaction can be achieved by providing quality service and all the facilities needed to make an informed decision about the service/product. 
Comprehensive description of services/products and effective customer support service would aid the customer in making a proper judgment. We can consider service quality, service description and customer support as the influencing factors of customer satisfaction and thus influencing competence trust in m-commerce.

H3: service quality, service description and customer support have positive influence in developing competence trust in mobile commerce vendors.

\begin{tabular}{|c|c|c|c|c|}
\hline \multirow{2}{*}{ Variables } & \multicolumn{4}{|c|}{ Sub-dimensions of Trust } \\
\cline { 2 - 5 } & $\begin{array}{c}\text { Accep- } \\
\text { tance }\end{array}$ & $\begin{array}{c}\text { Compe- } \\
\text { tence }\end{array}$ & $\begin{array}{c}\text { Benevo- } \\
\text { lence }\end{array}$ & $\begin{array}{c}\text { Predictab- } \\
\text { ility \& } \\
\text { Integrity }\end{array}$ \\
\hline Trust & $.777^{\star}$ & $.522^{\star}$ & $.691^{\star}$ & $.693^{\star}$ \\
Acceptance & 1 & $.593^{\star}$ & $.667^{\star}$ & $.737^{\star}$ \\
Competence & & 1 & $.574^{\star}$ & $.578^{\star}$ \\
Benevolence & & & 1 & $.752^{\star}$ \\
$\begin{array}{c}\text { Predictability \& } \\
\text { Integrity }\end{array}$ & & & & 1 \\
\hline
\end{tabular}

Benevolence trust in an m-commerce vendor is formed on the basis of empathy. User and security controls, incentives and privacy policies provided in the mobile websites demonstrate that the $\mathrm{m}$ commerce vendor is not opportunistic with regards to the customer's personal and transaction information. Thus we can consider user and security controls, incentives, and privacy policies as having a positive influence on benevolence trust.

H4: user and security controls, incentives and privacy policies have positive influence in developing benevolence trust in mobile commerce vendors.

Predictability trust and integrity trust emerge from a familiarity with the m-commerce vendor. Tan and Sutherland [27] in their work propose that predictability trust can be influenced by the perceived reputation of the m-commerce vendor and integrity trust by third party endorsements. From the above, we consider reputation and third party support to have a positive influence on predictability and integrity trust.

H5: Reputation and third party support have positive influence in developing predictability and integrity trust in mobile commerce vendors.

\section{RESULTS}

Table 1 shows bivariate correlations among different trust factors. The hypothesis H1 is supported. All sub-dimensions of trust are significantly correlated with trust. Thus, we can conclude that the single dimensional of trust and multi-dimension trust are moderately and highly correlated. This finding further amplifies the previous literature that trust is a multi-dimensional construct. Future researchers with limited resource can utilize trust or one of its subdimensions to investigate other mobile commerce adoption behaviors.
* Correlation is significant at the 0.01 level (2-tailed). Table 1: Correlation between Trust and its Subdimensions

To test hypotheses 2 through 5, we used stepwise regression analyses, which is suitable for this type of exploratory study. Table 2 shows the final results of how each significant independent variable predicts trust and its sub-dimension; all the non-significant predictors are not shown on the table.

\begin{tabular}{|c|c|c|c|c|c|c|c|}
\hline $\begin{array}{c}\text { Hypot- } \\
\text { hesis }\end{array}$ & $\begin{array}{c}\text { Dependent } \\
\text { Variables }\end{array}$ & $\begin{array}{c}\text { Significant } \\
\text { Predictor } \\
\text { Variables }\end{array}$ & $\begin{array}{c}\text { Adj. } \\
\mathbf{R}^{2}\end{array}$ & $\begin{array}{c}\text { Bet } \\
\mathbf{a}\end{array}$ & $\begin{array}{c}\mathbf{t}- \\
\text { value }\end{array}$ & $\begin{array}{c}\mathbf{p} \text { - } \\
\text { value }\end{array}$ & VIF \\
\hline $\mathrm{H} 2$ & Acceptance & $\begin{array}{c}\text { User } \\
\text { interface } \\
\text { design } \\
\text { Ubiquitous } \\
\text { connectivity }\end{array}$ & .290 & .332 & 3.176 & .002 & 1.108 \\
& $\mathrm{H} 3$ & $\begin{array}{c}\text { Service } \\
\text { Description } \\
\text { Customer } \\
\text { Support }\end{array}$ & .396 & .372 & 3.406 & .001 & 1.426 \\
& $\mathrm{e}$ & $\begin{array}{c}\text { Privacy } \\
\text { Policy } \\
\text { Incentive }\end{array}$ & .486 & .431 & 4.275 & .000 & 1.421 \\
& $\begin{array}{c}\text { Benevolenc } \\
\mathrm{e}\end{array}$ & $\begin{array}{c}\text { Reputation } \\
\mathrm{H} 5\end{array}$ & .162 & .417 & 3.866 & .000 & 1.000 \\
& $\begin{array}{c}\text { Predictabilit } \\
\text { and } \\
\text { Integrity }\end{array}$ & $\begin{array}{c}\text { Incentive } \\
\text { Privacy } \\
\text { Policy }\end{array}$ & .454 & .339 & 3.268 & .002 & 1.421 \\
\hline $\begin{array}{l}\text { Compa } \\
\text {-rison* }\end{array}$ & Trust & .438 & 4.222 & .000 & \\
\hline
\end{tabular}

* All predictor variables used.

Table 2: Hypothesis Testing Results

Hypothesis $\mathrm{H} 2$ refers to the influence of factors such as User interface design, ubiquitous connectivity, and contextual offers on acceptance trust in mobile commerce vendor. The results for hypothesis H2 indicates that user interface design and ubiquitous connectivity are significant at $\mathrm{p}<0.05$. Contextual offers was found to have a significance value of 0.155 which is more than 0.05 and hence is excluded from the model. This exclusion might be due to the fact that vendors have not extensively implemented contextual offers yet. Therefore, we can conclude that user interface design and ubiquitous connectivity 
provided by the mobile commerce vendor have a positive influence on consumers' acceptance trust.

The influence of the service quality, service description, and customer support factors on competence trust in mobile commerce vendor is discussed in hypothesis H3. The result indicates that service description and customer support are significant predictors of competence trust. Service quality was excluded from the regression model $(p=0.097)$. This exclusion is a puzzling one as one would typically associate the quality of a service with the competence of the vendor. One possible reason is that the more tangible factors (service description and customer support) are preferred over service quality as ones that portrays the competence nature of the mcommerce vendor. The adjusted R-Square with service description and customer support as predictors of competence trust is 0.396 . The analysis confirms that service description and customer support provided by the mobile commerce vendor have a positive influence on Competence trust developed by the consumers.

H4 hypothesis states that user and security controls, incentives and privacy policies have a positive impact on benevolence trust in mobile commerce vendor. Table 2 indicates that privacy policies and incentive predict benevolence trust $(\mathrm{p}<0.001)$. User control and security control were found to have insignificance values of 0.374 and 0.127 , respectively. One possible reason is that users found privacy policies listed on m-commerce vendor's websites sufficient enough to describe the benevolent nature of the service provider. The adjusted R-Square value with privacy policies and incentives as predictors of competence trust is 0.486 . Thus after analyzing the result we can confirm that privacy policies and customer support provided by the mobile commerce vendor has positive influence on benevolence trust developed by the customer.

Hypothesis $\mathrm{H} 5$ deals with the influence of reputation and third party support on predictability and integrity trust of mobile commerce vendor. Multiple regression analysis results for Hypothesis $\mathrm{H} 5$ are as shown in Table 2. The finding indicates that only reputation is a significant predictor of predictability and integrity trust $(\mathrm{p}<.001)$. Third party support has a significance value of 0.131 and was excluded. Similar to H4, one possible reason is that users found reputation sufficient enough to describe the predictability and integrity nature of the service provider. Another may be due to the small screen size of mobile devices - a third party seal may not appear on a screen unless the users scroll to the bottom portion of a page. The model has an adjusted RSquare value of .162 . Thus, the reputation of the mobile commerce vendor has positive influence on consumers' predictability and integrity trust.

It is interesting to observe from Table 2 that both Incentive and Privacy Policy are the predominant predictors of a single dimensional trust and benevolence trust. Such results point out the importance of value added mobile services and stringent privacy policies on building consumers' trust. Given all of the above, the model of this research can be summarized as:

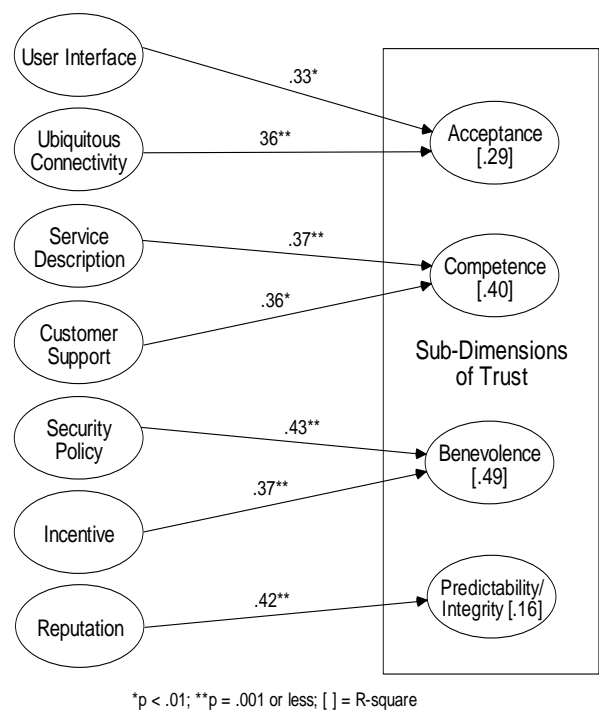

\section{CONCLUSIONS AND FUTURE RESEARCH}

As part of this research we initially recognized different factors that influenced trust in mobile commerce vendors and the different dimensions of trust through literature review. The focus of this study was to determine how the different trust factors influenced the different dimensions of trust. Data gathered from a survey was analyzed for the relationship between trust factors and the different dimensions of trust. User interface design and ubiquitous connectivity were found to influence acceptance trust. Good service description and customer support provided by mobile commerce vendor were found to have a positive effect on competence trust. Clearly stated privacy policies and incentives were found to play an influential role in developing benevolence trust in mobile commerce vendor and reputation of the mobile commerce vendor to directly influence predictability and integrity trust. 
Future research could be to expand the study and replace the student population by more a real world population and determine the relationship between the predictors of trust and its dimensions. Also, further regression analysis can be done on all the predictors and dimensions of trusts to form a more comprehensive model.

\section{REFERENCES}

1. Araujo, I. and Araujo, I., "Developing Trust In Internet Commerce", Proceedings of the 2003 conference of the Centre for Advanced Studies on Collaborative research, p.1 - 15, October 2003.

2. Asubonteng, P., McCleary, K.J. and Swan, J.E., "SERVQUAL Revisited: A Critical Review Of Service Quality", Journal of Services Marketing, Dec. 1996, Vol. 10, p. 62 - 81.

3. Burner II, G.C. and Kumar, A., "Explaining Consumer Acceptance Of Handheld Internet Devices", Journal of Business Research, 2005, pp. 553 - 558.

4. Gefen, D., "Customer Loyalty In E-Commerce", Journal of the Association for Information Systems (Volume 3, 2002), p. 27-51.

5. Gefen, D., "Reflections On The Dimensions Of Trust And Trustworthiness Among Online Consumers", ACM SIGMIS Database, Volume 33, Issue 3, summer 2002, Pages: 38 - 53.

6. Gefen, D., Karahanna, E. and Straub, D.W., "Trust And TAM In Online Shopping: An Integrated Model", MIS Quarterly, Vol. 27, No.1, pp. 51 - 90, March 2003.

7. GSM World Technology Website, Jan 2008, http://www.gsmworld.com.

8. Jin, L. and Miyazawa, T., "MRM Server: A Context-Aware And Location-Based Mobile ECommerce Server", Proceedings of the 2nd international workshop on Mobile commerce, September 2002, p. 33 - 39.

9. Keat, T. K. and Mohan, A. (2004) "Integration Of TAM Based Electronic Commerce Model For Trust”, Journal of American Academy of Business, vol. 5, no. 1/2, pp. 404 - 410.

10. Kim, J. and Hwang, C., "Applying The Analytical Hierarchy Process To The Evaluation Of Customer-Oriented Success Factors In Mobile Commerce", Proceedings of International Conference on Services Systems and Services Management (ICSSSM) 2005. Vol 1, page(s) 69 $-74$.

11. Kimery, K.M. and McCord. M., "Third-Party Assurances: Mapping The Road To Trust In ERetailing", Journal of Information Technology
Theory and Application; 2002; 4, 2; ABI/INFORM Global pg. 63.

12. Koukia, S., Rigou, M. and Sirmakessis, S., "The Role Of Context In M-Commerce And The Personalization Dimension", wi-iatw, pp. 267276, 2006 IEEE/WIC/ACM International Conferences on Web Intelligence and Intelligent Agent Technology - Workshops, 2006.

13. Lee, T. and Jun, J., "Contextual Perceived Usefulness? Toward An Understanding Of Mobile Commerce Acceptance", Proceedings of the international conference on mobile business 2005, p. $255-261$.

14. Lee, T., "The Impact Of Perceptions Of Interactivity On Customer Trust And Transaction Intentions In Mobile Commerce", Journal of Electronic Commerce Research, Vol.6, No. 3, 2005.

15. Liu, C. and Arnett, K.P., "Raising A Red Flag On Global WWW Privacy Policies", Journal of information systems, fall 2002, pg. 117.

16. Lu, F., Yu, C., Liu, C. and Yao, J., "Technology Acceptance Model For Wireless Internet", Electronic Networking Applications and Policy, Vol. 13, No. 3, 2003, pp. 206 - 222.

17. Mahatanankoon, P., Wen, J.H. and Lim, B., "Evaluating The Technological Characteristics And Trust Affecting Mobile Device Usage", International Journal of Mobile Communications, Vol. 4 No.6, pp.662-81.

18. Malloy, A.D., Varshney, U. and Snow, A.P., "Supporting Mobile Commerce Applications Using Dependable Wireless Networks", Mobile Networks and Applications, Volume 7, Number 3 / June, 2002.

19. McKnight, D.H., Choudhury, V. and Kacmar, C., "Trust In E-Commerce Vendors: A TwoStage Model", Proceedings of the $21^{\text {st }}$ international conference on Information systems, 2000, p. 532 - 536, ISBN: ICIS2000-X.

20. Menase, D.A., Barbara, D. and Dodge, R., "Preserving Qos Of E-Commerce Sites Through Self-Tuning: A Performance Model Approach", Proceedings of 2001 ACM Conference on E-commerce, Tampa, FL, October 14-17, 2001.

21. Salam, A.F., Rao, H.R. and Pegels, C.C., "Consumer-Perceived Risk In E-Commerce Transactions", Communications of the ACM, Mobile computing opportunities and challenges (ISSN: 0001-0782), December 2003, Vol. 46, Issue 12, p. 325 - 331.

22. Semrau, M. and Kraiss, A., "Mobile Commerce For Financial Services-Killer Applications Or Dead End?", ACM SIGGROUP Bulletin, volume 22, Issue 1, April 2001, p. 22 - 25. 
23. Siau, K. and Shen, Z., "Building Customer Trust In Mobile Commerce", Communications of the ACM, Digital rights management (ISSN:00010782), April 2003, Vol. 46, Issue 4, p. 91 - 94.

24. Siau, K., Lim, E. and Shen, Z. "Mobile Commerce: Promises, Challenges, And Research Agenda” Journal of Database Management 12, 3 (2001), 4-13.

25. Srinivasan, S.S., Anderson, R., and Ponnavolu, K., "Customer Loyalty In E-Commerce: An Exploration Of Its Antecedents And Consequences" Journal of Retailing, 78, 2002, pp. 41 - 50.

26. Suh, B. and Han, I., "The Impact Of Customer Trust And Perception Of Security Control On The Acceptance Of Electronic Commerce", International Journal of Electronic Commerce, Spring 2003, Vol. 7, No.3, pp. 135 - 161.

27. Tan, F.B. and Sutherland, P., "Online Customer Trust: A Multi-Dimensional Model", Journal of electronic commerce in organization, July - Sep 2004.

28. Venkatesh, V., Ramesh, V., and Massey, A.P., "Understanding Usability In Mobile Commerce", Communications of the ACM, SPECIAL ISSUE: Mobile commerce opportunities and challenges (ISSN:0001-0782), December 2003, Vol. 46, Issue 12, p. 53 - 56.

29. Xiong, L. and Liu, L., “Advances In Security And Payment Methods For Mobile Commerce", (ISBN: 1591403456) Chapter II, "Reputation and Trust”, Idea Group Inc.

30. Zhang, X. and Zhang, Q., "Online Trust Forming Mechanism: Approaches and an Integrated Model", Proceedings of the 7th international conference on Electronic commerce 2005, pages 201 - 209, August 15 - 17, 2005. 